UDC 633.11.631.527

(C)2014

Tishchenko V. N., Doctor of Agricultural Sciences, Professor,

Batashova M. E., Candidate of Biological Sciences, Shapochka O.M., Research Associate

Poltava State Agrarian Academy

\title{
INDIRECT METHODS OF SELECTION IN WINTER WHEAT BREEDING ON BASIS OF GENETIC CORRELATIONS
}

\section{Reviewer-Candidate of Biological Sciences A. V. Kolisnik}

3 метою покращчення селекційного процесу на продуктивністю були вивчені корелячї між врожайністю та рядом ознак та індексів у 170 ліній озимої пшенииі. Для пошуку найбільи ефективних методів оцінки зразків ми провели порівняння мінливості генетичних та екологічних корелячій. Використання таких індексів як атракції (маса зерна з колосу / маса колосу), мікророзподілень (маса зерна з колосу / маса полови колосу) та полтавський індекс (маса зерна $з$ колосу / довжина верхнього міжвузля) у непрямому доборі на ранніх етапах селекиії озимої пшениці забезпечить ефективну селекцію на високу продуктивність колосу. Одержані результати вказують на мінливість ознак та індексів в залежності від генотипу, гомозиготного чи гетерозиготного стану. Для підвищення ефективності добору важливим є пошук фенотипових кореляцій, де генетичний компонент направлений в одному напрямку, а екологічний в протилежному або близький до нуля. Коефічієнти кореляції збільшуються під впливом лімітуючих зовнішніх факторів та зменшуються в комфортних умовах для росту і розвитку рослин озимої пиениці.

Ключові слова: пшениця озима, лінії, ознаки, індекси, генетична кореляція, непрямий добір.

Statement of the problem. The left-bank foreststeppe Ukraine is major producer of cereals and winter wheat in particularly. It is characterized by continental climate with frost winters, spring delays, summer droughts and in whole by very unstable environmental conditions. Therefore the winter wheat grain production varies by years and in same years such as 2010 and 2011 its production decresed highly. The main causes of this are low resistance to frost and others abiotic and biotic factors. In Poltava region the modern commercial cultivars of Ukrainian and Russian breeding are cultivated and characterized by high productivity but low frost resistance. The creation of new intensive cultivars, with adaptation to the forest-steppe climate varying, demands special approaches to winter wheat breeding programs. Because the technology of individual and family selection under limiting environmental factors became promising way of plant breeding.
Analysis of recent research and publications, where it is started solving this problem. Finding the correlations between traits and indexes are idely applied in plant breeding. First V. A. Dragavtsev [2] established the considerable variability of genetic correlations depending on environment changing. Opposite direction of genetic and ecological correlations under the influence of limiting factors have been found for a number of quantitative traits and indexes [3].

One of the main methods of our breeding is index method. Besides the registration of main quality and quantity traits the accessions are estimating by the values of relative traits, or indexes. The index is a complex notion where the numerator is often some component of productivity and the denominator is the component of vegetative part. Our investigations showed that harvest index (HI), attraction index (AI), microdistribution (MDI), Poltavskiy index (our elaboration) (PI) are the most suitable for using on early breeding of winter wheat. These indexes have a high genetic correlation coefficients with yield per unit of area as compared with grain weight per plant and high heritability coefficient (74-76\% beside $42 \%$ by grain weight per ear) [4].

During different period of time various ways of breeding have been elaborated for many crops using the index method. The application of indexes may have the particular aim - establishing regularity or relationship, which is not visible on absolute values of traits, for searching unique genotypes with new useful performance. Index method provides wide opportunities for variability analysis and heritability of quantitative traits for correlation and cluster nalyses. It indicates ways of search and selection of productive genotypes by secondary, or marker traits and allows implement the search of such that may be used for individual and group selection on ifferent stages of breeding.

The aims of this research are:

1) to study the value and variability of genetic correlations of productivity traits and indexes in different winter wheat lines; 


\section{СІЛЬСЬКЕ ГОСПОДАРСТВО. РОСЛИННИЦТВО}

2) to make conclusions concerning to need to use a definite type of correlations in winter wheat breeding programs.

Materials and methods of the research. 106 lines from 16 crossing combinations that were obtained after individual selection in $\mathrm{F}_{2}$ have been investigated in two replications. The field experiments have been carried out in the experimental field of Poltava State Agrarian Academy. During plant development and after harvesting we have investigated such traits and indexes:

Traits: $\mathrm{H}$ - plant height, sm; WG - weight of grains in spike, g; WP - weight of plant, g; WS - weight of spike, g; WST - weight of stem, g; WSC - weight of spike chaff, g; WTG - weight of 1,000 grains, g; NG number of grains in spike; LS - length of spike, sm; AIL - apical internode length, sm; NS/m $\mathrm{m}^{2}$ - number of spikes per $1 \mathrm{~m}^{2}$; YG - yield of grain.

Indexes: $\mathrm{HI}-$ harvest index $=$ weight of grains in pike, g (WG) / weight of plant, g (WP); AI - attraction index = weight of spike, g (WS) / weight of stem, $\mathrm{g}$ (WST); MDI - microdistribution index = weight of grains in spike, $\mathrm{g}$ (WG) / weight of spike chaff (WSC); PI - Poltavskiy index = weight of grains in spike, $\mathrm{g}$ (WG) / apical internode length, sm (AIL); SPI - spike productivity index $=$ weight of grains in spike, $\mathrm{g}$ (WG) / weight of spike, g (WS).

Measurements have been made in 20 plants in each line and in 100 - in cultivars. Coefficients of genetic correlation (rg) were estimated by interline links, coefficients of ecological correlation (re) - by intravariety and intraline links. For the analysis of parcial correlations the following traits were chosen: yield of grain, $\mathrm{g} / \mathrm{m}^{2}$ (YG); weight of grains in spike, $\mathrm{g}$ (WG); number of grains in spike $(\mathrm{NG})$, weight of 1,000 grains, $\mathrm{g}$ (WTG), number of spikes per $1 \mathrm{~m}^{2}$ $\left(\mathrm{NS} / \mathrm{m}^{2}\right)$. Statistical analyses were performed by the software package STATISTICA.

Results. A new program of selection and genetic esearch has been developed by us since 1999 based on ecological and genetic approach. It is aimed at creating varieties with improved parameters of yield, quality, adaptability and other useful characteristics.

For searching the most effective methods of estimating winter wheat accessions we have used omparison of genetic correlations variability with ecological correlations variability of different traits and indexes. The variability of genetic and ecological correlations between some productivity traits and indexes was investigated (tabl. 1).

Attraction index (AI) - weight of spike, g (WS) / weight of stem, $g$ (WST). It reflects the outflow of assimilative plastic matters from vegetative organs (stem, leaves) into generative (spike). Table 1 shows that AI have negative average and close genetic correlation (rg) with stem traits (H, AIL, WST), with EL, WP and WTG - low and unreliable. Average and close positive rg were with NG. There was close ositive rg between AI and HI. Ecological correlations differed from genetic, they were low and unreliable, excluding WST. Thus, attraction index defines ormating number of flowers in spike, and accodingly the number of grains, without influencing WTG.

\section{Coefficients of genetic rg and ecological re correlations between investigated quantitative traits and indexes in winter wheat lines}

\begin{tabular}{|c|c|c|c|c|}
\hline \multirow{2}{*}{ Trait, index } & \multicolumn{4}{|c|}{ rg/re } \\
\cline { 2 - 5 } & Weight of grain & Attraction index & $\begin{array}{c}\text { Micro } \\
\text { distribution index }\end{array}$ & $\begin{array}{c}\text { Poltavskiy } \\
\text { index }\end{array}$ \\
\hline Plant height & $-.48 / .21$ & $-.81 / .08$ & $-.14 * /-.28^{*}$ & -.51 \\
\hline Weight of grain & - & $.48 / .00$ & $.45 / .32$ & .84 \\
\hline Weight of plant & $.54 / .89$ & $-.19 * /-.14^{*}$ & $-.49 / .00$ & .27 \\
\hline Weight of spike & $.82 / .85$ & $.47 / .23$ & $.00 / .00$ & .59 \\
\hline Weight of spike & .65 & $-.68 /-.59$ & $-.58 / .15^{*}$ & $-.16^{*}$ \\
\hline Number of grains & $.85 / .88$ & $.68 / .03^{*}$ & $.17 * / .37$ & .77 \\
\hline Weight of 1,000 gr & $.55 / .41$ & $.06^{*} / .06^{*}$ & $.73 / .08$ & .35 \\
\hline Harvest index & $.72 / .58$ & $.80 / .10^{*}$ & $.75 / .66$ & .76 \\
\hline Attraction index & $.48 / .00$ & - & $.29 /-.40$ & .69 \\
\hline Microdistribution i. & $.45 / .32$ & $.29 /-.40$ & - & .59 \\
\hline Poltavskiy index & .84 & $.69 / .00$ & $.59 / .50$ & - \\
\hline Apical internode 1. & $-.09 *$ & $-.48 / .00$ & $-46 / .00$ & .00 \\
\hline Length of spike & .26 & $-.04 * / .10^{*}$ & $-.52 / .00$ & .30 \\
\hline
\end{tabular}




\section{СІЛЬСЬКЕ ГОСПОДАРСТВО. РОСЛИННИЦТВО}

Microdistribution index (MDI) - weight of grains in spike, g (WG) / weight of spike chaff (WSC). It reflects the outflow assimilative plastic matters from vegetative part of the spike to grains.

Table 1 shows that MDI have negative and low correlations with stem traits (H, AIL, WST). With WG trait $\mathrm{rg}$ and re were positive. The tendency to negative genetic correlation when ecological is nreliable between MDI - LS and WS traits was received. The increase of spike length leads to the appearance the sterile flowers on the basis and pical part of the spike. As a result, MDI decreases and chaff weight increases after maturing.

It $\mathrm{h}$ established that grain development in the spike basis and in its apical part are controlled by different genes [1], and they are all part of epigenic system, that determines the MDI value. So, the selection of genotpes with maximum MDI and optimal spike length will provide the creation of winter wheat lines and varieties with complete spike.

The genetic correlation between AI and MDI was low positive (0.29) and confirm the conclusions of Dyakov and Dragavtsev that AI and MDI are ontrolled by two independent genetic systems. It allows combining the best characteristics of both indexes in one genotype by hybridization and election. The application of indirect selection on the early winter wheat breeding by optimal combination of $\mathrm{AI}$ and MDI in one genotype will provide effective breeding for high spike productivity.

The using of HI for analysis of great amount of plants is sufficiently laborious. Because we have use a new index Poltavskiy (PI) of our elaboration (Tishchenko, Chekalin 2005). PI is characterized by close positive correlation with spike productivity traits and negative correlations with stem traits $(\mathrm{H}, \mathrm{AIL}$, WST), the high heritability coefficient $\left(h^{2}=0.51\right)$, the simplicity of PI measuring. It allows estimating a large amount of breeding material during a short period etween harvesting and sowing winter wheat. Poltavskiy index $(\mathrm{PI})=$ weight of grains in spike, $\mathrm{g}(\mathrm{WG}) /$ apical internode length, sm (AIL). The given data concerning correlation of PI with main quantitative traits and indexes indicate to its successful application in winter wheat breeding.

The obtained results indicate at the variability of traits and indexes depending on the genotype, homo- or heterozygote state. For increasing the fficiency of selection it is very important to find phenotype correlations where the genetic component is directed one way and the ecological is opposite or near zero. In our case the correlations of such type were between: $\mathrm{WG}-\mathrm{H}$; $\mathrm{WG}-\mathrm{AI}$; $\mathrm{AI}-\mathrm{H}$; $\mathrm{AI}-\mathrm{HI}$; AI - NG; AI - MDI; AI - AIL; MDI - WP; MDI WST; MDI - WTG; MDI - AIL; MDI - LS (table 1). Their values are marked in the table.

The influence of fluctuate environmental conditions by years and sowing terms at the gene expression determine variation of genetic corretions between the indexes and productivity characteristics. In this experiment the lines with max and min values of weight of grains in spike, $g(W G)$, the number of grains in spike (NG), weight of 1,000 grains (WTG), yield, $\mathrm{t} / \mathrm{h}(\mathrm{Y})$ were selected (table 2).

The obtained data showed that the harvest index (HI) had more close genetic correlations with min values of all productivity traits. By the attraction index (AI) the picture was the same excluding WTG and correlations were not as strongly different as by HI. Correlations between AI and WTG were reliable but low. Poltavskiy index (PI) had very close correlation with WG (0.75-0.85) and NG (0.73$0.75)$ without depending of trait value. The rg of PI with WTG was unreliable, with Y was very close in case of min trait value: $\operatorname{rg}=0.90, \mathrm{Y}=2.9 \mathrm{t} / \mathrm{h}$. Spike productivity index (SPI) had more close correlations in cases of min trait value with WG, WTG and Y, but rg was not high.

\section{Variation of genetic correlations (rg) between indexes and productivity traits in depend of their min and max values}

\begin{tabular}{|c|c|c|c|c|c|c|}
\hline \multirow{2}{*}{ Traits } & \multicolumn{2}{|c|}{ Value } & \multicolumn{4}{c|}{ rg } \\
\cline { 3 - 7 } & & HI & AI & PI & SPI \\
\hline \multirow{2}{*}{ WG, g } & $\max$ & 2,2 & 0,49 & 0,38 & 0,75 & 0,48 \\
\cline { 2 - 6 } & $\min$ & 0,87 & 0,82 & 0,69 & 0,85 & 0,60 \\
\hline \multirow{2}{*}{ NG } & $\max$ & 42,5 & 0,47 & 0,36 & 0,73 & 0,48 \\
\cline { 2 - 7 } & $\min$ & 29,4 & 0,69 & 0,49 & 0,75 & 0,18 \\
\hline \multirow{2}{*}{ WTG, g } & $\max$ & 51,8 & 0,18 & 0,20 & $0,27 *$ & 0,29 \\
\cline { 2 - 7 } & $\min$ & 37,6 & 0,42 & 0,18 & $-0,02^{*}$ & 0,48 \\
\hline \multirow{2}{*}{$\mathrm{Y}, \mathrm{t} / \mathrm{h}$} & $\max$ & 5,79 & 045 & 0,37 & .60 & 0,21 \\
\cline { 2 - 7 } & $\min$ & 2,90 & 0,76 & 0,50 & .90 & 0,71 \\
\hline
\end{tabular}

* - correlation coefficient is unreliable 
СІЛЬСЬКЕ ГОСПОДАРСТВО. РОСЛИННИЦТВО

\section{Genetic coefficients variation (CV\%) of WG, NG, WTG in winter wheat lines during different years of investigation}

\begin{tabular}{|c|c|c|c|c|c|}
\hline № & Years, terms & WG & NG & WTG & NS/m ${ }^{2}$ \\
\hline 1 & 2007-early sowing & 13,94 & 14,69 & 7,70 & 16,65 \\
\hline 2 & 2007-late sowing & 16,65 & 15,75 & 6,81 & 17,40 \\
\hline 3 & 2008-early sowing & 15,89 & 13,50 & 10,77 & 16,40 \\
\hline 4 & 2008-late sowing & 15,35 & 12,90 & 11,80 & 17,66 \\
\hline 5 & 2009-early sowing & 13,54 & 12,59 & 7,95 & 16,65 \\
\hline 6 & 2009-late sowing & 11,44 & 11,26 & 7,33 & 16,35 \\
\hline 7 & 2010-early sowing & 19,96 & 14,67 & 15,88 & 18,92 \\
\hline 8 & 2010-late sowing & 20,04 & 13,11 & 17,02 & 18,59 \\
\hline 9 & 2011-early sowing & 12,95 & 10,40 & 7,48 & 15,63 \\
\hline 10 & 2011-late sowing & 13,01 & 9,99 & 7,98 & 15,72 \\
\hline 11 & 2012-early sowing & 19,48 & 17,71 & 13,93 & 20,60 \\
\hline 12 & 2012-late sowing & 19,46 & 17,02 & 8,81 & 18,68 \\
\hline 13 & 2013-early sowing & 16,52 & 14,95 & 8,30 & 15,95 \\
\hline 14 & 2013-late sowing & 14,95 & 12,43 & 7,62 & 15,50 \\
\hline
\end{tabular}

Winter wheat is characterized by autumn-winterspring environment factors that influence on the umber of spikes per $1 \mathrm{~m}^{2}\left(\mathrm{NS} / \mathrm{m}^{2}\right)$ : frost resistance, presence of genes of sensibility to photoperiod, ecessity of definite duration of vernalization, «per se» genes and others. Genotype differences between lines generally are reflected in the number of plants which survived winter and on $\mathrm{NS} / \mathrm{m}^{2}$ trait accordingly. In this connection the coefficient of variation (CV\%) of $\mathrm{NS} / \mathrm{m}^{2}$ is higher than other traits such as WG, NG и WTG in different year conditions in the most variants (tabl. 3).

Conclusions. The indirect selection method by the values of indexes may be effectively used for winter wheat breeding programs.

Attraction index has shown close genetic correlation with the number of grains in spike, which indicates on its principal contribution to spike productivity on early stages of plant development.

\section{REFERENCES}

1. Dyakov A. V., Dragavtsev V. A. Конкурентноспособность растений в связи сселекцией. Надежность оценки генотипов по фенотипам / А. В. Дьяков, В. А. Драгавцев // Генетика. - 11, № 5. - 1975. - C. 11-22.

2. Dragavtsev V. A. and others. Модель экологогенетического контроля количественных признаков растений / В. А. Драгавцев, П. П. Литун, Н. М. Шкель, Н. Н. Нечипоренко // Доклады АН
Microdistribution index has demonstrated close correlation with the weight of thousand grains, which indicates that MDI determines the outflow of plastic matters to grains beginning from flowering phase. The application of indirect selection on the early winter wheat breeding by optimal combination of $\mathrm{AI}$ and MDI in one genotype will provide effective breeding for high spike productivity.

The using of new index Poltavskiy (PI) of our elaboration allows estimating a large amount of breeding material during a short period between harvesting and sowing winter wheat. PI is characterized by close positive correlation with spike productivity traits, the high heritability coefficient and the simplicity of measuring.

Correlation coefficients increased under the influence of limiting environment factors and decreased in comfortable conditions for growth and development of winter wheat plants.

CCCP. - 1984. - T. 274. - №3. - C. 720-723.

3. Chekalin N. M. Use of inderect selection in rain legume breding / In: 2nd European Conf. on Grain Legumes, Copenhagen, 1995. - P. 200.

4. Tishchenko V. N., Chekalin N. M. Генетические основы адаптивной селекции озимой пшеницы в зоне Лесостепи. / В. Н. Тищенко, Н. М. Чекалин. - Полтава, 2005. - 270 с. 